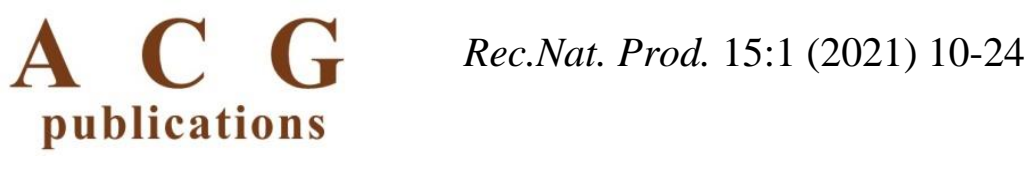

records of natural

products

\title{
The Leaf and the Gall Volatiles of Salvia fruticosa Miller from Turkey: Chemical Composition and Biological Activities
}

\author{
Sevda Süzgeç-Selçuk ${ }^{(*}{ }^{*}$ Temel Özek ${ }^{2,3}$, Gülmira Özek ${ }^{2}$, \\ Süleyman Yur ${ }^{2,3}$, Fatih Göger $\oplus^{2,3}$, M. Bahar Gürdal ${ }^{4}$, \\ Gizem Gülsoy Toplan $\oplus^{1}$, Ali H. Meriçli ${ }^{5}$ and K.Hüsnü Can Başer $\oplus^{5}$ \\ ${ }^{1}$ Istanbul University, Faculty of Pharmacy, Department of Pharmacognosy, 34116 Istanbul, Türkiye \\ ${ }^{2}$ Anadolu University, Faculty of Pharmacy, Department of Pharmacognosy, 26470, Eskişehir, Türkiye \\ ${ }^{3}$ Medicinal Plant, Drug and Scientific Research and Application Center (AUBIBAM), Anadolu \\ University, 26470 Eskişehir, Türkiye \\ ${ }^{4}$ Istanbul University, Faculty of Pharmacy, Department of Pharmaceutical Botany, 34116, Istanbul, \\ Türkiye \\ ${ }^{5}$ Near East University, Faculty of Pharmacy, Department of Pharmacognosy, Nicosia, \\ Turkish Republic of Northern Cyprus
}

(Received March 11, 2020; Revised June01, 2020; Accepted June 02, 2020)

\begin{abstract}
In this study two different extraction techniques namely, conventional hydrodistillation (HD) and microsteam distillation-solid-phase microextraction (MSD-SPME), were used to analyze the volatile constituents from the leaves and the galls of Salvia fruticosa Mill. by gas chromatography (GC-FID) and gas chromatography coupled to mass spectrometry (GC-MS). The oxygenated monoterpenes (62.4-69.3\%) were found to be predominating compound group with 1,8-cineole and camphor as the main constituents in all the tested samples with the exception of the gall oil in which oxygenated sesquiterpenes $(25.6 \%)$ and diterpenes $(17.3 \%)$ were detected in high percentages. Qualitative differences of the volatiles obtained by HD and MSD-SPME techniques from the leaf and the galls are discussed. The resulting leaf essential oils were evaluated for their in vitro acetylcholinesterase (AChE) inhibition potential. In vitro DPPH scavenging, and Cupric Reducing Antioxidant Capacity (CUPRAC) assays were used to evaluate the leaf essential oils. AChE inhibition $41.2 \%$ and antioxidant $36.8 \%$ assays results showed moderate levels of activity. In this present study, to the best of our knowledge comparative leaf and gall volatiles of S. fruticosa was reported for first time.
\end{abstract}

Keywords: Salvia fruticosa; galls; acetylcholinesterase, antioxidant; SPME; GC-MS. (C) 2020 ACG Publications. All rights reserved.

\section{Introduction}

Turkey has a great variety of biotic and abiotic diversity, i.e. climatic, edaphic, geographicgeologic, and pollinator diversity. These factors lead Turkey to be one of the most important plant

\footnotetext{
* Corresponding author: E-Mail: sevdasuzgec@ hotmail.com Phone:090-212-4400000 Fax:090-212-4400252 
biodiversity centers in the world with over 10.000 plant species and ca. $35 \%$ endemism ratio. There are 100 species and 107 taxa of Salvia in the flora of Turkey. Rate of endemism on taxon basis is 54\% Lamiaceae is the third largest family in Turkey with 46 genera, 782 taxa comprising 603 species and 179 subspecies and varieties. 346 taxa (271 species and 75 subspecies and varieties) are endemic. Endemism ratio is ca. 44\% [1, 2]. The genus Salvia (sage) is one of the largest genera of Lamiaceae. Although Salvia has lower number of taxa in the Mediterranean phytogeographic region than the Irano-Turanian phytogeographic region in Turkey, endemism ratio is higher in the Mediterranean phytogeographic region [1]. In the Flora of Turkey, 100 Salvia species and 107 taxa are recorded, 58 of which are endemic taxa and endemism ratio $54 \%[1,3]$.

Sage has probably been used since 1400 B.C. because it was illustrated in the "blue bird fresco" in the House of Frecoes, Knossos [4]. Several Salvia species have important commercial value on the herbal market, Salvia officinalis L., S. triloba L. fil. (Syn. S. fruticosa Miller), S. lavandulaefolia Vahl., $S$. verbenaca L. and S. sclarea L. S. tomentosa Miller is another species with development potential. While Salvia officinalis is cultivated worldwide, and S. sclarea in Europe and North America, S. fruticosa oil is produced from wild plants as well as from cultivated ones [5]. Most Salvia species (69\%) are moderately rich in oil $(0.1-1.0 \%)$. Nine taxa (14\%), which comprise commercial species, contained $>1 \%$ oil. Salvia taxa of Turkey were classified by Baser (2002) according to main components in their respective essential oils. Commercial Salvia species belong to the following groups: CiCa $(1,8-$ cineole/camphor) group, $S$. fruticosa (syn. $S$. triloba); pinene $(\alpha / \beta)$ group, $S$. tomentosa; thujone $(\alpha / \beta)$ group, S. officinalis, S. pomifera (syn. S. calycina) [6]. The actual situation of sage oil production and export (mainly in Mediterranean countries) was reported by Baser. In Turkey, approximately $500 \mathrm{~kg}$ of the leaf oil from S. triloba (S. fruticosa) is annually produced and 600 tons of sage leaves worth more than 1.5 million US\$ are exported in 1996. The sage oil is produced from $S$. fruticosa (wild) in Manisa and Alanya provinces of Turkey. The local people call the sage oil "elma yaği" (apple oil) due to resemblance of galls (apples) growing on its leaves and stems to small apples [7].

The literature survey revealed a number of ethnopharmacological reports about $S$. fruticosa usage in folk medicine: diarrhea [8], colds and abdominal pain [9], antiseptic, dyspepsia, tonsillitis [5, 10]. Also it is used for the treatment of burn by sowing the dried $S$. fruticosa leaves after being powdered [11].

Pharmacological properties and biological activities of the essential oils and extracts $S$. fruticosa have been reported such as anti-inflammatory [12], antioxidant [13, 14], antimicrobial [15], antifungal [16], anticancer [17], antilipolytic and hypotriglyceridemic [18], hypoglycemic [19], acetylcholinesterase inhibition [20], butyrylcholinesterase inhibition [21], pancreatic lipase inhibition [22].

Previous phytochemical investigations of $S$. fruticosa showed the occurrence of flavonoids [2325], phenolic acids [25, 26], fatty acids [27], mono-, sesqui-, di- and triterpenoids, steroids [28-30]. There are number of essential oil reports of S. fruticosa from different regions of Turkey [30-33] however, detailed GC-MS analyses of the essential oils of the leaf and the galls have not been reported.

Aim of our work was to evaluate chemical composition of the oils obtained from the leaves and the galls of $S$. fruticosa growing in Turkey. In scope of the present work, we carried out the gas chromatographic analysis of the essential oils obtained by hydrodistillation (HD) and micro-steam distillation-solid-phase microextraction (MSD-SPME) techniques from the leaves and the galls of $S$. fruticosa.

Essential oil (EO) of S. fruticosa was evaluated in vitro for memory-enhancing effect via inhibition of the acetylcholinesterase (AChE) enzyme. Inhibition of AChE can be considered as a promising strategy for the treatment neurological diseases including Alzheimer's disease (AD), senile dementia, ataxia, myasthenia gravis, Parkinson's disease, amyotrophic lateral sclerosis etc. [34-38]. According to cholinergic hypothesis, $\mathrm{AD}$ is characterized by reduction in the activity of the cholinergic neurons [39]. Up to date, many attempts have been carried out to find effective anti-AChE drugs. For instance, galanthamine from Galanthus nivalis L. [40], eserin from Physostigma venenosum L. [41], huperzin A from Huperzia serrata (Thumb.) Trev. [42] possess pharmacologically proven anti-AChE activity. Galanthamine is applied clinically in USA and EU. However, eserin cannot be used in treatments because of side effects and huperzin A is still in phase-III clinical trials in China [43]. A comprehensive 
review on natural anti-AChE agents has recently been published by Topcu [44]. There are reports about anti-AChE activity of essential oils obtained from Citrus aurantifolia Swingle, $C$. aurantium L., and $C$. bergamia Risso and Poit. Peels [45], Origanum ehrenbergii Boiss. and O. syriacum L. [46], Acorus calamus [47], Salvia lavandulifolia Spreng. [48]. The strong anti-cholinesterase potential of the extracts and essential oils from many Salvia species $[39,49,50]$ prompted us to investigate the oil of $S$. fruticosa for memory enhancing potential.

\section{Experimental}

\subsection{Plant Material}

The leaf (L) and gall apple (G) of Salvia fruticosa Miller (Syn: S. triloba L.) (LI-GI, LII-GII and LIII-GIII) were collected from different localities of Turkey. The leaf and gall containing specimens of $S$. fruticosa are deposited at the Herbarium of the Faculty of Pharmaceutical Botany of the Istanbul University and Herbarium of the Faculty of Pharmaceutical Botany of the Marmara University, Turkey.

S. fruticosa LI-GI was collected in August 2007 from Muğla-Torba, Turkey. It was identified by Prof. Dr. Ertan Tuzlac1 and has been deposited at the Herbarium of Faculty of Pharmacy, Marmara University with specimen number, MARE No: 11109a. S. fruticosa LII-GII was collected in May 2009 from Muğla, Marmaris-Bayır village, Turkey and also $S$. fruticosa LIII-GIII was collected in September 2009 from Tekirdağ, Gaziköy-Şarköy, Turkey. S. fruticosa LII-GII and S. fruticosa LIII-GIII were identified by Dr. Bahar Gürdal and have been deposited at the Herbarium of Faculty of Pharmacy, Istanbul University with specimen numbers, ISTE No: 91439 and ISTE No: 86111 respectively.

\subsection{General}

Agilent 5975 GC-MSD system (Agilent Technologies, Santa Clara, USA) equipped with the HPInnowax FSC column $(60 \mathrm{~m} \times 0.25 \mathrm{~mm}$ id with $0.25 \mu \mathrm{m}$ film thickness, Agilent, USA). The GC-FID analysis was carried out with capillary GC using an Agilent 6890N GC system (Agilent Technologies, Santa Clara, USA). Absorbance was recorded with Biotek Powerwave XS microplate reader. SPME fiber coated with PDMS-DVB (polydimethylsiloxane - divinylbenzene) $65 \mu \mathrm{m}$ "blue type" was provided from Supelco (Supelco Park, Bellefonte, PA, USA). Before use, the fiber was reconditioned in accordance to manufacture recommendations.

\subsection{Chemicals}

2,2-Diphenyl-1-picrylhydrazyl (DPPH), anhydrous sodium sulphate (ACS-ISO, for analysis), sodium chloride, magnesium chloride hexahydrate, Tris(hydroxymethyl) aminomethane (ACS reagent), acetylcholinesterase (AChE) from Electrophorus electricus (electric eel, Type VI-S, 200-1,000 units/mg protein), bovine serum albumin (BSA), acetylthiocholine iodide (ATCI), 5,5'-dithiobis(2-nitrobenzoic acid) (DTNB), sodium phosphate, disodium phosphate, cupper chloride, ammonium acetate, neocuproine (Nc) and galanthamine hydrobromide from Lycoris sp. were purchased from Sigma-Aldrich (St. Louis, MO, USA). $n$-Hexane (ACS, for analysis) was purchased from Carlo Erba (Italy). Sodium chloride (extra pure) was obtained from Merck (Darmstadt, Germany). A $\mathrm{C}_{9}-\mathrm{C}_{40} n$-alkane standard solution was purchased from Fluka (Buchs, Switzerland).

\subsection{Isolation of Essential Oil}

\subsubsection{Hydrodistillation}

The essential oils were isolated separately from the dried and ground herb and the galls of $S$. fruticosa by hydrodistillation (HD) using a Clevenger type apparatus according to a procedure described in the European Pharmacopoeia [51]. The oil yield was calculated on a dry weight basis, dried over anhydrous sodium sulfate, and stored in sealed vials in refrigerator $\left(4^{\circ} \mathrm{C}\right)$, until GC-FID and GC-MS 
analyses. The oil was dissolved in $n$-hexane $(10 \%, \mathrm{v} / \mathrm{v})$ to conduct chromatographic determination of its composition.

\subsubsection{MSD-SPME Technique}

Volatiles were isolated with MSD-SPME (micro-steam distillation-solid-phase microextraction) technique from the plant material using device described earlier [52]. The dried and ground plant material was placed in $25 \mathrm{~mL}$ round bottom flask used as refluxing vessel along with $5 \mathrm{~mL}$ of water. The flask was fitted with a Claisen distillation head with plug and a condenser set up for refluxing rather than distillation. MSD-SPME was performed on $0.5 \mathrm{~g}$ plant material with 1.0 min reflux. Heating was achieved using electric heater, and threaded plug was used for SPME fiber assembly. A manual SPME holder (57330-U, Supelco, Bellefonte, PA) and the PDMS-DVB $65 \mu \mathrm{m}$ fiber "blue-type" were used for SPME procedure of volatiles. Fiber was conditioned at $250^{\circ} \mathrm{C}$ for $30 \mathrm{~min}$ before the experiment. After the SPME needle pierced the plug, the fiber was expressed through the needle and exposed to the headspace above a plant sample. After the trapping of volatile, the loaded SPME fiber was withdrawn into the needle, and then the needle was removed from the plug and subsequently used for GC-FID and GC-MS analyses. Desorption of the analytes from the fiber coating was performed by heating the fiber in the injection port to $250^{\circ} \mathrm{C}$ for $5 \mathrm{~min}$. The analytes were then transferred directly into the chromatographic column for analysis. Afterwards, the SPME fiber was reconditioned at $250^{\circ} \mathrm{C}$ for the next extraction experiment for $30 \mathrm{~min}$. The fiber was subjected to a blank injection to ensure fiber integrity and the absence of any analytes after each reconditioning period. Experiments were performed in triplicate.

\subsection{Chemical Composition of the Essential Oil}

\subsubsection{Gas Chromatography-Mass Spectrometry (GC-MS)}

The volatiles were analyzed by GC-FID and GC-MS techniques. The GC-MS analysis was carried out with an Agilent 5975 GC-MSD system (Agilent, Technologies, Santa Clara, USA). HP-Innowax FSC column $(60 \mathrm{~m} \times 0.25 \mathrm{~mm}, 0.25 \mu \mathrm{m}$ film thickness, Agilent, Walt \& Jennings Scientific, Wilmington, DE, USA) was used with a helium carrier gas at $0.8 \mathrm{~mL} / \mathrm{min}$. GC oven temperature was kept at $60^{\circ} \mathrm{C}$ for 10 min and programmed to $220^{\circ} \mathrm{C}$ at a rate of $4^{\circ} \mathrm{C} / \mathrm{min}$, kept constant for $10 \mathrm{~min}$ at $220^{\circ} \mathrm{C}$, and then programmed to increase at a rate of $1{ }^{\circ} \mathrm{C} / \mathrm{min}$ to $240^{\circ} \mathrm{C}$. The oil was analyzed with a split ratio of 40:1. The injector temperature was $250^{\circ} \mathrm{C}$. Mass spectra were taken at $70 \mathrm{eV}$ and the mass range was from $\mathrm{m} / z$ 35 to 450 . Experiments were performed in triplicate.

\subsubsection{Gas Chromatography (GC)}

The GC-FID analysis was carried out with capillary GC using an Agilent 6890N GC system (Agilent Technologies, Santa Clara, USA). Flame ionization detector (FID) temperature was set at $300^{\circ} \mathrm{C}$ in order to obtain the same elution order with GC-MS. Simultaneous injection was performed using the same column and appropriate operational conditions. Experiments were performed in triplicate.

\subsubsection{Identification and Quantification of Compounds}

Identification of the compounds was performed according to the following: (i) comparison of the GC-MS Relative Retention Indices (RRI) of the compounds on polar column determined relative to the retention times of a series of $n$-alkanes $\left(\mathrm{C}_{9}-\mathrm{C}_{40}\right)$, with those of authentic compounds or literature data; (ii) computer matching with commercial mass spectral libraries: MassFinder software 4.0, Adams Library, Wiley GC-MS Library (Wiley, New York, NY, USA) and NIST Library, and comparison of the recorded spectra with literature data [53-56]. Confirmation was also achieved using the in-house "Başer Library of Essential Oil Constituents" database, obtained from chromatographic runs of pure compounds performed 
with the same equipment and conditions [57]. Percent composition was obtained for each constituent on the basis of GC-FID analyses of the oils.

\subsection{Anti-Acetylcholinesterase Assay}

Acetylcholinesterase (AChE) inhibition of the samples was evaluated using Ellman's method as previously reported [58]. Three buffers were used in the experiment: (A) $50 \mathrm{mM}$ Tris- $\mathrm{HCl}(\mathrm{pH}=8.0$, in ultrapure water); (B) $0.1 \%$ BSA in buffer A; (C) $0.1 \mathrm{M} \mathrm{NaCl}$ and $0.02 \mathrm{M} \mathrm{MgCl}_{2} \cdot 6 \mathrm{H}_{2} \mathrm{O}$ in buffer A. In the 96-well flat bottom plates, $25 \mu \mathrm{L}$ sample (EO/ reference compound), $50 \mu \mathrm{L}$ buffer B and $25 \mu \mathrm{L}$ AChE $\left(0.22 \mathrm{U} / \mathrm{mL}\right.$ in buffer A) solution were mixed and incubated for $15 \mathrm{~min}$ at $25^{\circ} \mathrm{C}$. Then, $125 \mu \mathrm{L}$ Ellman's reagent DTNB ( $3.0 \mathrm{mM}$ in buffer C) and $25 \mu \mathrm{L}$ substrate ATCI $(15 \mathrm{mM}$, in ultrapure water) were added. The mixture allowed to stand $15 \mathrm{~min}$ at $25^{\circ} \mathrm{C}$ and the absorbances were recorded at $412 \mathrm{~nm}$. Similarly, a blank (for eliminating the colors of the samples) was prepared by adding sample solution to all reaction reagents and $25 \mu \mathrm{L}$ buffer instead of enzyme. The control wells contained all the reagents without the sample (the solvent of the sample instead was added). Galanthamine hydrobromide $(0.1 \mathrm{mg} / \mathrm{mL})$ was used as positive control. The percentage inhibition was calculated according to equation:

$$
\% \text { Inh }=\left[\frac{\left(A b s_{\text {control }}-A b s_{\text {control blank }}\right)-\left(A b s_{\text {sample }}-A b s_{\text {sample blank }}\right)}{A b s_{\text {control }}-A b s_{\text {control blank }}}\right] \times 100
$$

where $\mathrm{Abs}_{\text {control }}$ and $\mathrm{Abs}_{\text {control blank }}$ are the absorbances of the control and its blank, $\mathrm{Abs}_{\text {sample }}$ and $\mathrm{Abs}_{\text {sample }}$ blank are the absorbances of the sample and its blank.

\subsection{Antioxidant Assays}

\subsubsection{Cupric Reducing Antioxidant Capacity (CUPRAC)}

The cupric ion reducing capacity of EO was determined according to the method of Apak et al. [59] with slight modifications. The EO solution $(3.75 \mathrm{mg} / \mathrm{mL})$, gallic acid $(0.01 \mathrm{mg} / \mathrm{mL})$ and ascorbic acid $(0.1$ $\mathrm{mg} / \mathrm{mL})$ solutions were prepared in methanol. $\mathrm{CuCl}_{2}$ solution $\left(1.0 \times 10^{-2} \mathrm{M}\right)$ and ammonium acetate buffer (1.0 M, pH 7.0) were prepared in ultrapure water. Neocuproine $(\mathrm{Nc})$ solution $\left(7.5 \times 10^{-3} \mathrm{M}\right)$ was prepared in absolute ethanol. $55 \mu \mathrm{L}$ sample solution (EO / reference compound), $50 \mu \mathrm{L} \mathrm{CuCl}_{2}$ solution, $50 \mu \mathrm{L} \mathrm{Nc}$ solution and $50 \mu \mathrm{L}$ ammonium acetate buffer were placed by multichannel automatic pipette (Eppendorf Research ${ }^{\circledR}$ plus, Germany) into 96-flat bottom well plate cells and allowed to stand in the dark for 30 min. The control well contained the same reagents except sample (methanol was added). After incubation at $25^{\circ} \mathrm{C}$ for $30 \mathrm{~min}$, the absorbance at $450 \mathrm{~nm}$ of wells was measured using an ELISA microplate reader (Biotek Powerwave XS).

\subsubsection{Free Radical Scavenging Assay (DPPH test)}

The scavenging effect of the sample on DPPH free radical was determined using a modified method of Brand-Williams [60]. The solution of EO $(3.75 \mathrm{mg} / \mathrm{mL})$, gallic acid $(0.01 \mathrm{mg} / \mathrm{mL})$ and ascorbic acid $(0.1 \mathrm{mg} / \mathrm{mL})$ were prepared in methanol. $100 \mu \mathrm{L}$ of the sample (EO / reference compound) solution was mixed with $100 \mu \mathrm{L}$ DPPH solution $(0.08 \mathrm{mg} / \mathrm{mL}$ in $\mathrm{MeOH})$ in 96 -flat bottom well plate cells. 100 $\mu \mathrm{L}$ methanol mixed with $100 \mu \mathrm{L}$ of DPPH was used as control. The mixtures allowed to stand in the dark for $30 \mathrm{~min}$. Decrease in the absorbance was recorded at $517 \mathrm{~nm}$. Gallic acid $(0.01 \mathrm{mg} / \mathrm{mL})$ and ascorbic acid $(0.1 \mathrm{mg} / \mathrm{mL})$ were used as positive control. Experiments were performed in triplicate. The free radical scavenging activity of the sample was expressed as percentage of inhibition calculated according to equation: 


$$
\text { Inh } \%=\left(\frac{A b s_{\text {control }}-A b s_{\text {sample }}}{A b s_{\text {control }}}\right) \times 100
$$

where $\mathrm{Abs}_{\text {control }}$ is the absorbance of the control (containing all reagents except the test sample), Abs sample $_{\text {s }}$ is the absorbance of the sample with added DPPH.

\section{Results and Discussion}

\subsection{Chemical Composition}

Our work aimed to analyze the essential oil compositions of $S$. fruticosa leaves and galls and to investigate the biological proporties of its leaves' essential oil. Hydrodistillation of S. fruticosa yielded yellowish essential oils (EO)(2.3-3.0\%) with a specific odor from the leaves and $0.10-0.12 \%$ from the gall. The GC-FID and GC-MS analyses allowed us to determine qualitative and quantitative profiles of the leaf and the gall volatiles of $S$. fruticosa. The list of detected compounds with their relative percentages, retention indices and method of identification is given in Table 1 in order of their elution on the HP-Innowax FSC column.

GC-FID and GC-MS analyses of the leaf oils obtained by hydrodistillation of $S$. fruticosa from three collection sites (I), (II) and (III), resulted in the characterization of 52 to 70 constituents corresponding to $96.0-98.9 \%$ of the oils. The essential oil composition is considered to be more complex than previous studies [30].

The gall oils analyses revealed 41-51 compounds constituting 92.1-98.1\% of the oils. The volatile constituents detected in the leaf and the galls were classified as mono-, sesqui- and diterpenes, and fatty acids. As can be seen from Table 1, the leaf oils demonstrate differences in percentage of major constituents. The major oxygenated monoterpene, 1,8-cineole (27.2\%) was detected in lower amount in L(I)-HD oil than in L(II)-HD and L(III)-HD EOs (47.1\% and 46.7\%, respectively). Meanwhile, camphor was found in higher amount (19.8\%) than those of the other leaf oils $(9.3 \%)$. Among the monoterpene hydrocarbons a quantitative difference was noted for camphene, which accounted for $10.7 \%$ in L(I)-HD oil while in the other leaf oils it was $3.7 \%$ and $3.8 \%$. Topçu et al. reported higher amount of 1,8-cineole $(58.9 \%)$ [30].

Chemical composition of EOs obtained by hydrodistillation of the galls of $S$. fruticosa from three collection sites (I), (II) and (III) was found to differ significantly from the leaf oils. The big difference was detected in the amount of the main compound 1,8-cineole, whose percentage was down to $1.7 \%$ in G(I)-HD, and to $13.1 \%$ and $12.9 \%$ in G(II)-HD and G(III)-HD oils, respectively. Similarly, the percentage of camphor decreased to $3.2 \%$ in G(I)-HD oil, while in the G(II)-HD and G(III)-HD gall oils it was $21.3 \%$ and $21.0 \%$. The sesquiterpenes were found in higher amount (up to 11.9\%) in G(I)-HD oil than in other galls with $\beta$-caryophyllene (7.9\%) and viridiflorol (8.6\%) as major representatives. The gall oils were characterized with significant amount of diterpenes (5.2-17.2\%) while in the leaf oils they were detected in scarce amount $(0.8 \%)$. Manool $(15.7 \%)$ was found to be the major constituent of the G(I)-HD oil. Another noteworthy fact is high percentage of fatty acids in the gall oil with hexadecanoic acid (14.8\%) as the major compound in G(I)-HD EO.

According to literature data, climatic, and ecological differences as well as environmental conditions besides genetic variations could be responsible for the differences in the essential oil composition of $S$. fruticosa [61].

Distribution of the major compound groups in the leaf and the gall oils of S. fruticosa are represented in Figure S1. As can be seen, all the oils are rich with oxygenated monoterpenes with the exception of G(I)-HD oil in which oxygenated sesquiterpenes and diterpenes predominated over other compounds. 
The leaf and the gall volatiles of Salvia fruticosa Miller

Table 1. Chemical constituents of essential oils obtained from the leaves and the galls of Salvia fruticosa with HD and MSD-SPME techniques [62-85]

\begin{tabular}{|c|c|c|c|c|c|c|c|c|c|c|c|}
\hline RRI & RRI range (Ref.) & Compound & L(I)-HD & $\begin{array}{c}\text { L(I)-MSD- } \\
\text { SPME }\end{array}$ & L(II)-HD & L(III)-HD & G(I)-HD & $\begin{array}{c}\text { G(I)-MSD- } \\
\text { SPME }\end{array}$ & G(II)-HD & G(III)-HD & $\begin{array}{c}\text { ID } \\
\text { Method }\end{array}$ \\
\hline 1014 & $1012-1015^{\mathrm{a}}$ & Tricyclene & - & - & 0.1 & 0.1 & - & - & $\mathrm{t}$ & $\mathrm{t}$ & $\mathrm{a}, \mathrm{b}, \mathrm{c}$ \\
\hline 1032 & $1008-1039^{a}$ & $\alpha$-Pinene & 7.1 & 4.0 & 5.8 & 5.7 & 2.9 & 5.9 & 3.9 & 3.8 & $a, b, c$ \\
\hline 1035 & $1012-1039^{a}$ & $\alpha$-Thujene & $\mathrm{t}$ & $\mathrm{t}$ & 0.1 & 0.1 & - & - & $\mathrm{t}$ & $\mathrm{t}$ & $a, b, c$ \\
\hline 1076 & $1043-1086^{a}$ & Camphene & 10.7 & 4.3 & 3.9 & 3.8 & 4.1 & 6.1 & 5.5 & 5.4 & $a, b, c$ \\
\hline 1118 & $1085-1130^{a}$ & $\beta$-Pinene & 5.7 & 1.8 & 5.8 & 5.8 & 1.7 & 1.4 & 5.1 & 5.0 & $a, b, c$ \\
\hline 1174 & $1140-1175^{\mathrm{a}}$ & Myrcene & 2.9 & 4.5 & 2.6 & 2.6 & 1.8 & 1.6 & 1.3 & 1.3 & $a, b, c$ \\
\hline 1188 & $1154-1195^{\mathrm{a}}$ & $\alpha$-Terpinene & - & - & 0.2 & 0.2 & - & - & - & - & $\mathrm{a}, \mathrm{b}, \mathrm{c}$ \\
\hline 1195 & $1167-1197^{\mathrm{a}}$ & Dehydro-1,8-cineole & $\mathrm{t}$ & $\mathrm{t}$ & - & - & - & - & - & - & $a, b, c$ \\
\hline 1203 & $1178-1219^{a}$ & Limonene & 1.8 & $\mathrm{t}$ & 1.3 & 1.3 & 0.9 & 0.9 & 2.1 & 2.0 & $a, b, c$ \\
\hline 1212 & $1177-1205^{\mathrm{b}, \mathrm{c}}$ & Sylvestrene & - & - & $\mathrm{t}$ & - & - & - & - & - & $a, b, c$ \\
\hline 1213 & $1186-1231^{\mathrm{a}}$ & 1,8-Cineole & 27.2 & 34.1 & 47.1 & 46.7 & 1.7 & 32.4 & 13.1 & 12.9 & $\mathrm{a}, \mathrm{b}, \mathrm{c}$ \\
\hline 1218 & $1188-1233^{a}$ & $\beta$-Phellandrene & - & - & - & - & - & - & $\mathrm{t}$ & - & $a, b, c$ \\
\hline 1255 & $1222-1266^{a}$ & $\gamma$-Terpinene & $\mathrm{t}$ & 1.9 & 0.3 & 0.3 & - & - & - & 0.1 & $a, b, c$ \\
\hline 1266 & $1230-1280^{\mathrm{a}}$ & 3-Octanone & - & - & 0.1 & 0.1 & - & - & - & - & $a, b, c$ \\
\hline 1267 & $1232-1267^{a}$ & $(E)-\beta$-Ocimene & $\mathrm{t}$ & 0.2 & - & - & - & - & - & 0.1 & $a, b, c$ \\
\hline 1280 & $1246-1291^{a}$ & $p$-Cymene & $\mathrm{t}$ & 1.2 & 0.7 & 0.7 & 0.6 & 1.7 & 0.8 & 0.8 & $a, b, c$ \\
\hline 1290 & $1261-1300^{a}$ & Terpinolene & 0.1 & 0.1 & 0.2 & 0.2 & - & - & $\mathrm{t}$ & 0.1 & $a, b, c$ \\
\hline 1386 & $1386^{\mathrm{d}}$ & Octenyl acetate & 0.1 & $\mathrm{t}$ & - & - & - & - & - & - & $a, b, c$ \\
\hline 1437 & $1435^{\mathrm{e}, \mathrm{f}}$ & $\alpha$-Thujone & 3.4 & 4.5 & 1.9 & 1.9 & 0.5 & 6.3 & 3.5 & 3.4 & $a, b, c$ \\
\hline 1451 & $1456^{\mathrm{g}}$ & $\beta$-Thujone & 2.6 & 4.2 & 1.3 & 1.3 & 0.4 & 4.0 & 1.4 & 1.4 & $a, b, c$ \\
\hline 1452 & $1411-1465^{a}$ & 1-Octen-3-ol & 0.1 & - & - & - & - & - & - & - & $a, b, c$ \\
\hline 1474 & $1438^{\mathrm{h}}$ & trans-Sabinene hydrate & 0.3 & 0.2 & 0.2 & 0.2 & - & - & - & - & $a, b, c$ \\
\hline 1494 & $1494^{\mathrm{i}}$ & (Z)-3-Hexenyl 3-methylbutyrate & - & - & $\mathrm{t}$ & $\mathrm{t}$ & - & - & - & - & $\mathrm{b}, \mathrm{c}$ \\
\hline 1497 & $1462-1522^{a}$ & $\alpha-$ Copaene & $\mathrm{t}$ & 0.2 & - & - & $\mathrm{t}$ & 0.1 & - & - & $a, b, c$ \\
\hline 1532 & $1481-1537^{\mathrm{a}}$ & Camphor & 19.8 & 26.2 & 9.3 & 9.3 & 3.2 & 21.8 & 21.3 & 21.0 & $a, b, c$ \\
\hline 1535 & $1496-1546^{\mathrm{a}}$ & $\beta$-Bourbonene & $\mathrm{t}$ & $\mathrm{t}$ & - & - & - & - & - & - & $\mathrm{a}, \mathrm{b}, \mathrm{c}$ \\
\hline 1553 & $1507-1564^{\mathrm{a}}$ & Linalool & 0.6 & 0.3 & 0.4 & 0.5 & 0.3 & 0.3 & 1.8 & 1.8 & $a, b, c$ \\
\hline 1556 & $1526-1565^{a}$ & cis-Sabinene hydrate & 0.2 & $\mathrm{t}$ & 0.1 & 0.1 & - & - & - & - & $a, b, c$ \\
\hline 1565 & $1532-1570^{\mathrm{a}}$ & Linalyl acetate & 0.6 & 0.5 & 0.5 & 0.5 & 0.3 & 0.7 & 2.4 & 2.4 & $a, b, c$ \\
\hline 1571 & $1557-1625^{\mathrm{a}}$ & trans-p-Menth-2-en-1-ol & $\mathrm{t}$ & - & - & - & - & - & - & - & $\mathrm{a}, \mathrm{b}, \mathrm{c}$ \\
\hline 1572 & $1589^{\mathrm{j}}$ & Acetoxy linalooloxide & $\mathrm{t}$ & - & - & - & - & - & - & - & $\mathrm{b}, \mathrm{c}$ \\
\hline 1590 & $1570-1592^{\mathrm{a}}$ & Bornyl acetate & 1.9 & 2.4 & 0.5 & 0.5 & 1.2 & 0.8 & 0.8 & 0.7 & $a, b, c$ \\
\hline 1592 & $1550-1603^{a}$ & $\beta$-Copaene & - & - & - & - & $\mathrm{t}$ & - & - & - & $a, b, c$ \\
\hline 1594 & $1518-1602^{a}$ & Camphene hydrate & $\mathrm{t}$ & $\mathrm{t}$ & - & - & - & - & - & - & $a, b, c$ \\
\hline
\end{tabular}




\begin{tabular}{|c|c|c|c|c|c|c|c|c|c|c|c|}
\hline RRI & RRI range (Ref.) & Compound & L(I)-HD & $\begin{array}{l}\text { L(I)-MSD- } \\
\text { SPME }\end{array}$ & L(II)-HD & L(III)-HD & G(I)-HD & $\begin{array}{c}\text { G(I)-MSD- } \\
\text { SPME }\end{array}$ & G(II)-HD & G(III)-HD & $\begin{array}{c}\text { ID } \\
\text { Method }\end{array}$ \\
\hline 1610 & $1564-1618^{a}$ & Calarene $(=\beta$-Gurjunene $)$ & - & - & 0.1 & - & - & - & - & - & $\mathrm{a}, \mathrm{b}, \mathrm{c}$ \\
\hline 1611 & $1564-1630^{\mathrm{a}}$ & Terpinen-4-ol & 0.5 & 0.9 & 0.9 & 0.1 & 0.1 & 0.1 & - & - & $a, b, c$ \\
\hline 1612 & $1569-1617^{a}$ & $\beta$-Caryophyllene & 1.5 & 1.4 & 2.3 & 3.1 & 7.9 & 2.6 & 2.1 & 2.1 & $a, b, c$ \\
\hline 1628 & $1583-1668^{a}$ & Aromadendrene & 0.1 & 0.2 & 0.2 & 0.2 & 0.9 & 0.2 & $\mathrm{t}$ & 0.2 & $a, b, c$ \\
\hline 1629 & $1632^{\mathrm{k}}$ & 2-Methyl-6-methylene-3,7-octadien-2-o & ol t & - & - & - & - & - & - & - & $\mathrm{c}$ \\
\hline 1636 & $1694^{1}$ & Sylveterpineol & - & - & - & 0.2 & - & - & - & 0.4 & $\mathrm{~b}, \mathrm{c}$ \\
\hline 1638 & $1555-1645^{\mathrm{a}}$ & cis-p-Menth-2-en-1-ol & $\mathrm{t}$ & $\mathrm{t}$ & - & - & - & - & - & - & $a, b, c$ \\
\hline 1658 & $1660^{\mathrm{a}}$ & Sabinyl acetate & 0.1 & 0.1 & - & - & - & - & - & - & $a, b, c$ \\
\hline 1661 & $1624-1668^{a}$ & Alloaromadendrene & - & - & 0.1 & - & - & - & - & - & $\mathrm{b}, \mathrm{c}$ \\
\hline 1670 & $1643-1671^{a}$ & trans-Pinocarveol & $\mathrm{t}$ & 0.1 & - & 0.1 & - & - & $\mathrm{t}$ & 0.2 & $a, b, c$ \\
\hline 1682 & $1655-1687^{a}$ & $\delta$-Terpineol & 0.1 & $\mathrm{t}$ & 0.9 & 1.0 & - & - & - & 0.4 & $a, b, c$ \\
\hline 1687 & $1637-1689^{a}$ & $\alpha$-Humulene & 0.2 & 0.1 & 1.0 & 1.0 & 2.8 & 0.9 & 1.4 & 1.4 & $a, b, c$ \\
\hline 1700 & $1662-1717^{a}$ & $p$-Mentha-1,8-dien-4-ol & $\mathrm{t}$ & $\mathrm{t}$ & - & - & - & - & - & - & $a, b, c$ \\
\hline 1704 & $1655-1714^{a}$ & $\gamma$-Muurolene & - & - & $\mathrm{t}$ & 0.1 & 0.1 & 0.2 & 0.2 & 0.2 & $a, b, c$ \\
\hline 1706 & $1659-1724^{\mathrm{a}}$ & $\alpha$-Terpineol & 0.2 & 0.3 & 2.8 & 3.0 & - & - & 0.6 & 0.8 & $a, b, c$ \\
\hline 1709 & $1672-1718^{a}$ & $\alpha$-Terpinyl acetate & - & - & 1.9 & 1.7 & - & - & 4.1 & 4.7 & $a, b, c$ \\
\hline 1710 & $1708^{\mathrm{n}}$ & Ledene & - & - & - & - & $\mathrm{t}$ & 0.1 & - & - & $\mathrm{a}, \mathrm{b}, \mathrm{c}$ \\
\hline 1719 & $1653-1728^{a}$ & Borneol & 4.4 & 3.6 & 1.4 & 1.5 & 2.2 & 2.7 & 2.2 & 3.0 & $a, b, c$ \\
\hline 1733 & $1693-1740^{\mathrm{a}}$ & Neryl acetate & 0.1 & 0.1 & - & - & - & - & 0.2 & 0.2 & $\mathrm{a}, \mathrm{b}, \mathrm{c}$ \\
\hline 1740 & $1686-1753^{a}$ & $\alpha$-Muurolene & - & - & $\mathrm{t}$ & $\mathrm{t}$ & - & - & - & - & $\mathrm{a}, \mathrm{b}, \mathrm{c}$ \\
\hline 1741 & $1688-1761^{\mathrm{a}}$ & Valencene & $\mathrm{t}$ & 0.1 & - & - & - & - & - & - & $a, b, c$ \\
\hline 1758 & $1668-1771^{\mathrm{a}}$ & cis-Piperitol & $\mathrm{t}$ & - & - & - & - & - & - & - & $a, b, c$ \\
\hline 1763 & $1708^{a}$ & Zonarene & - & - & - & 0.1 & - & - & - & - & $\mathrm{b}, \mathrm{c}$ \\
\hline 1765 & $1728-1772^{\mathrm{a}}$ & Geranyl acetate & 0.1 & 0.1 & 0.1 & $\mathrm{t}$ & - & - & 0.5 & 0.5 & $a, b, c$ \\
\hline 1773 & $1722-1774^{\mathrm{a}}$ & $\delta$-Cadinene & 0.1 & 0.3 & 0.1 & 0.1 & 0.2 & 0.1 & 0.1 & 0.1 & $a, b, c$ \\
\hline 1776 & $1735-1782^{a}$ & $\gamma$-Cadinene & $\mathrm{t}$ & 0.1 & $\mathrm{t}$ & $\mathrm{t}$ & $\mathrm{t}$ & 0.1 & 0.1 & 0.2 & $a, b, c$ \\
\hline 1804 & $1743-1808^{a}$ & Myrtenol & 0.1 & 0.1 & - & - & - & - & 0.2 & - & $a, b, c$ \\
\hline 1845 & $1805-1850^{\mathrm{a}}$ & trans-Carveol & $\mathrm{t}$ & - & - & - & - & - & - & - & $\mathrm{a}, \mathrm{b}, \mathrm{c}$ \\
\hline 1853 & $1800-1853^{\mathrm{a}}$ & cis-Calamenene & 0.1 & 0.1 & 0.1 & 0.1 & $\mathrm{t}$ & 0.2 & 0.3 & 0.6 & $a, b, c$ \\
\hline 1864 & $1813-1865^{\mathrm{a}}$ & p-Cymen-8-ol & $\mathrm{t}$ & $\mathrm{t}$ & $\mathrm{t}$ & - & - & - & - & - & $\mathrm{a}, \mathrm{b}, \mathrm{c}$ \\
\hline 1878 & $1826-1878^{a}$ & 2,5-Dimethoxy-p-cymene & $\mathrm{t}$ & - & - & - & - & - & - & - & $a, b, c$ \\
\hline 1882 & $1818-1882^{\mathrm{a}}$ & cis-Carveol & $\mathrm{t}$ & - & - & - & - & - & - & - & $\mathrm{a}, \mathrm{b}, \mathrm{c}$ \\
\hline 1941 & $1893-1941^{\mathrm{a}}$ & $\alpha$-Calacorene & - & - & 0.1 & - & - & - & - & 0.1 & $a, b, c$ \\
\hline 2008 & $1936-2023^{a}$ & Caryophyllene oxide & 1.2 & $\mathrm{t}$ & 0.8 & 0.8 & 3.5 & 0.1 & 2.6 & 2.5 & $a, b, c$ \\
\hline 2045 & $2071^{0}$ & Humulene epoxide-I & $\mathrm{t}$ & $\mathrm{t}$ & 0.1 & 0.1 & 0.5 & 0.1 & 0.3 & 0.3 & $a, b, c$ \\
\hline
\end{tabular}




\begin{tabular}{|c|c|c|c|c|c|c|c|c|c|c|c|}
\hline RRI & RRI range (Ref.) & Compound & L(I)-HD & $\begin{array}{c}\text { L(I)-MSD- } \\
\text { SPME }\end{array}$ & L(II)-HD & L(III)-HD & G(I)-HD & $\begin{array}{c}\text { G(I)-MSD- } \\
\text { SPME }\end{array}$ & G(II)-HD & G(III)-HD & $\begin{array}{c}\text { ID } \\
\text { Method }\end{array}$ \\
\hline 2050 & $1995-2055^{\mathrm{a}}$ & $(E)$-Nerolidol & - & - & - & - & - & - & $\mathrm{t}$ & - & $a, b, c$ \\
\hline 2071 & $2003-2071^{a}$ & Humulene epoxide-II & 0.2 & $\mathrm{t}$ & - & 0.5 & 1.9 & $\mathrm{t}$ & 2.3 & 2.3 & $\mathrm{~b}, \mathrm{c}$ \\
\hline 2081 & $2081^{p}$ & Humulene epoxide-III & - & - & - & $\mathrm{t}$ & 0.3 & $\mathrm{t}$ & 0.1 & 0.1 & $\mathrm{~b}, \mathrm{c}$ \\
\hline 2098 & $2049-2104^{\mathrm{a}}$ & Globulol & $\mathrm{t}$ & $\mathrm{t}$ & 0.1 & 0.1 & 0.2 & 0.4 & - & - & $a, b, c$ \\
\hline 2104 & $2041-2110^{a}$ & Viridiflorol & 0.7 & 0.1 & 1.3 & 1.3 & 8.6 & 0.1 & 3.4 & 3.3 & $a, b, c$ \\
\hline 2131 & $2041-2110^{\mathrm{a}}$ & Hexahydro farnesylacetone & - & - & - & - & - & - & - & 0.1 & $a, b, c$ \\
\hline 2144 & $2074-2150^{\mathrm{a}}$ & Spathulenol & 0.1 & $\mathrm{t}$ & 0.1 & 0.1 & 0.4 & $\mathrm{t}$ & $\mathrm{t}$ & - & $\mathrm{a}, \mathrm{b}, \mathrm{c}$ \\
\hline 2179 & $2123-2174^{\mathrm{a}}$ & Tetradecanol & - & - & - & - & 0.2 & $\mathrm{t}$ & - & - & $a, b, c$ \\
\hline 2180 & $2249^{\mathrm{q}}$ & Pimara-8,15-diene & - & - & - & - & 0.1 & $\mathrm{t}$ & - & 0.1 & $\mathrm{~b}, \mathrm{c}$ \\
\hline 2187 & $2184^{r}$ & T-Cadinol & $\mathrm{t}$ & $\mathrm{t}$ & - & - & - & - & - & - & $\mathrm{a}, \mathrm{b}, \mathrm{c}$ \\
\hline 2192 & $2110-2196^{\mathrm{a}}$ & Nonanoic acid & - & - & - & - & - & - & - & 0.1 & $a, b, c$ \\
\hline 2198 & $2100-2205^{\mathrm{a}}$ & Thymol & 0.1 & $\mathrm{t}$ & - & - & 0.6 & 0.2 & - & - & $\mathrm{a}, \mathrm{b}, \mathrm{c}$ \\
\hline 2217 & $2238^{\mathrm{s}}$ & Clovenol & $\mathrm{t}$ & $\mathrm{t}$ & $\mathrm{t}$ & 0.1 & 0.4 & $\mathrm{t}$ & 0.2 & 0.1 & $a, b, c$ \\
\hline 2239 & $2140-2246^{\mathrm{a}}$ & Carvacrol & 0.1 & $\mathrm{t}$ & - & - & - & - & - & - & $a, b, c$ \\
\hline 2255 & $2180-2255^{\mathrm{a}}$ & $\alpha$-Cadinol & $\mathrm{t}$ & $\mathrm{t}$ & - & $\mathrm{t}$ & - & - & - & - & $\mathrm{a}, \mathrm{b}, \mathrm{c}$ \\
\hline 2265 & $2231^{\mathrm{t}}$ & Torilenol & $\mathrm{t}$ & $\mathrm{t}$ & - & - & - & - & - & - & $a, b, c$ \\
\hline 2300 & $2289^{u}$ & Cinnamyl isovalerate & $\mathrm{t}$ & - & - & - & - & - & - & - & $a, b, c$ \\
\hline 2316 & $2316^{\circ}$ & Caryophylla-2(12),6(13)-dien-5 $\beta$-ol & $\mathrm{t}$ & $\mathrm{t}$ & - & 0.2 & 0.2 & $\mathrm{t}$ & - & - & $\mathrm{a}, \mathrm{b}, \mathrm{c}$ \\
\hline 2324 & $2324^{\mathrm{a}}$ & Caryophylla-2(12),6(13)-dien-5a-ol & 0.2 & 0.1 & 0.2 & 0.4 & 1.9 & 0.2 & 0.8 & 0.8 & $a, b, c$ \\
\hline 2389 & $2389^{v}$ & Caryophylla-2(12),6-dien-5 $\alpha-$ ol & 0.3 & 0.1 & 0.4 & 0.3 & 4.6 & 0.2 & 1.3 & 1.3 & $a, b, c$ \\
\hline 2389 & $2389^{t}$ & Eremophilone & - & - & - & - & - & - & - & 0.1 & $\mathrm{~b}, \mathrm{c}$ \\
\hline 2390 & $2351-2402^{\mathrm{a}}$ & Eudesma-4(15),7-dien-1 $\beta$-ol & $\mathrm{t}$ & - & - & - & - & - & - & - & $a, b, c$ \\
\hline 2392 & $2392^{u}$ & Caryophylla-2(12),6-dien-5 $\beta$-ol & 0.3 & $\mathrm{t}$ & 0.3 & - & 3.5 & 0.1 & 1.1 & 1.0 & $a, b, c$ \\
\hline 2503 & $2442-2524^{\mathrm{a}}$ & Dodecanoic acid & - & - & - & - & - & - & 0.7 & - & $a, b, c$ \\
\hline 2524 & $2476-2530^{\mathrm{a}}$ & Abietatriene & - & - & - & - & $\mathrm{t}$ & $\mathrm{t}$ & 0.3 & 0.7 & $\mathrm{~b}, \mathrm{c}$ \\
\hline 2681 & $2370-2628^{a}$ & Manool & 0.8 & $\mathrm{t}$ & 0.7 & 0.7 & 15.7 & 0.1 & 4.9 & 5.1 & $\mathrm{~b}, \mathrm{c}$ \\
\hline 2732 & $2735^{y}$ & Labda-7,14-dien-13-ol & $\mathrm{t}$ & - & 0.1 & 0.1 & 1.4 & - & $\mathrm{t}$ & 0.5 & $a, b, c$ \\
\hline \multirow[t]{4}{*}{2931} & $2862-2945^{\mathrm{a}, \mathrm{z}}$ & Hexadecanoic acid & - & - & - & - & 14.8 & - & 3.8 & 2.4 & $a, b, c$ \\
\hline & & Total & 96.7 & 84.0 & 98.5 & 98.9 & 92.1 & 92.7 & 96.8 & 98.1 & \\
\hline & & Oil yield, \% & 3.0 & - & 2.3 & 2.1 & 0.10 & - & 0.12 & 0.12 & \\
\hline & & Compounds detected & 70 & 60 & 52 & 53 & 41 & 40 & 47 & 51 & \\
\hline
\end{tabular}

L(I)-HD: Leaf volatiles (I) obtained by the hydrodistillation in Clevenger type apparatus; L(I)-MSD-SPME: Leaf volatiles (I) obtained by MSD-SPME technique; G(I)-HD: Gall apple volatiles (I) obtained by the hydrodistillation in Clevenger type apparatus; G(I)-MSD-SPME: Gall apple volatiles (I) obtained by MSD-SPME technique; L(II)-HD: Leaf volatiles (II) obtained by the hydrodistillation in Clevenger type apparatus: G(II)-HD: Gall apple volatiles (II) obtained by the hydrodistillation in Clevenger type apparatus; RRI: Relative retention indices calculated against $n$-alkanes; \%: calculated from FID data; t: Trace (<0.1\%); a) Identification based on retention index of genuine compounds on the HP-Innowax column; $\mathbf{b}$ ) Identification on the basis of computer matching of the mass spectra and retention times from Başer Library, $\mathbf{c})$ Identification
on the basis of computer matching of the mass spectra from Adams, MassFinder, WileyNIST libraries. References in table: a: [62], b:[63], c:[64], d:[65], e:[66],f:[67], g:[68], h:[69], i:[70], j:[71], k:[72], l:[73], m:[74], on the basis of computer matching of the mass spectra from Adams, MassFinder,
$\mathbf{n}:[75], \mathbf{o}:[76], \mathbf{p : [ 7 7 ] , ~} \mathbf{q}:[78], \mathbf{r}:[79], \mathbf{s : [ 8 0 ] , ~ t : [ 8 1 ] , ~ u : [ 8 2 ] , ~ v : [ 8 3 ] , ~} \mathbf{y}:[84], \mathbf{z :}:[85]$ 
In scope of the present study, together with conventional hydrodistillation procedure, a modern and rapid microscale technique MSD-SPME was applied to isolate volatiles from the leaves and the galls of S. triloba. MSD-SPME is known as a rapid, modern and trustworthy technique applied for isolation of volatiles from very small amount of plant material for the short time [86-88]. MSD-SPME can be attributed to new sampling and concentration techniques which involved concurrent solid-phase microextraction combined with continuous hydrodistillation of the volatiles. This technique combined with GC-FID and GC-MS methods provided important advantages in time saving for performing the quickly analysis of a number of samples. It is very important to notify that MSD-SPME is energy saving, solvent-less and non-toxic technique for the volatiles analysis at microscale level. In scope of the experiment three additional runs using different amounts of the plant material and different periods for reflux were performed for optimization of extraction process. As a result, the volatiles were isolated from $0.5 \mathrm{~g}$ plant material for $1.0 \mathrm{~min}$. The chromatographic profiles of the leaf and the gall volatiles obtained with conventional HD and with MSD-SPME are compared and presented on Figure 2. As can be seen, MSD-SPME technique allowed to isolate leaf volatiles with profile similar to that obtained with conventional method. However, the oil hydrodistilled from the galls significantly differed from the volatiles isolated with MSD-SPME technique. Diterpenes and fatty acids were found in high amount in G(I)-HD oil while SPME procedure resulted with volatiles rich in oxygenated monoterpenes (1,8-cineole and camphor, Figure S2 and Table 1) Perhaps subjection to longer distillation procedure ( $3 \mathrm{~h}$ ) resulted with diterpenes and fatty acid extraction in case of HD method.

\subsection{Anti-acetylcholinesterase Activity of Essential Oil}

Up to date, many attempts have been made to find effective sage EOs with anti-AChE property It has recently been reported that EO of $S$. pseudeuphratica Rech.f. possess significant inhibitory activity against AChE ( $\mathrm{IC}_{50} 26.00 \mu \mathrm{g} / \mathrm{mL}$ ) [21, 25, 48]. Topçu et al. reported that $S$. fruticosa EO inhibited AChE with $53.6 \%$ (at concentration $25 \mu \mathrm{g} / \mathrm{mL}$ ) [44]. The oil of $S$. fruticosa oil collected from Cyprus demonstrated human anti-AChE activity with $\mathrm{IC}_{50} 0.05 \mathrm{mg} / \mathrm{mL}$ [21]. However, these EOs possess qualitative differences as compared to composition of L(I)-HD and L(II)-HD oils investigated in the present work.

In scope of our work the leaf oils L(I)-HD and L(II)-HD were investigated in vitro for memory vitalizing activity using Ellmans's method which uses an alternative substrate ATCI and chromogenic agent DTNB. The reaction results in production of 5-thio-2-nitrobenzoate that has yellow color due to the shift of electrons to the sulfur atom [89]. The percentage of the inhibition of AChE was determined by comparison of rates of reaction of test EOs relative to blank sample (methanol in phosphate buffer). The results of AChE inhibition test are presented in Table 2. As can be seen from the Table 2, the leaf oils inhibited AChE with 40-41\%.

Table 2. Biological activity results of the leaf EOs obtained from S. fruticosa

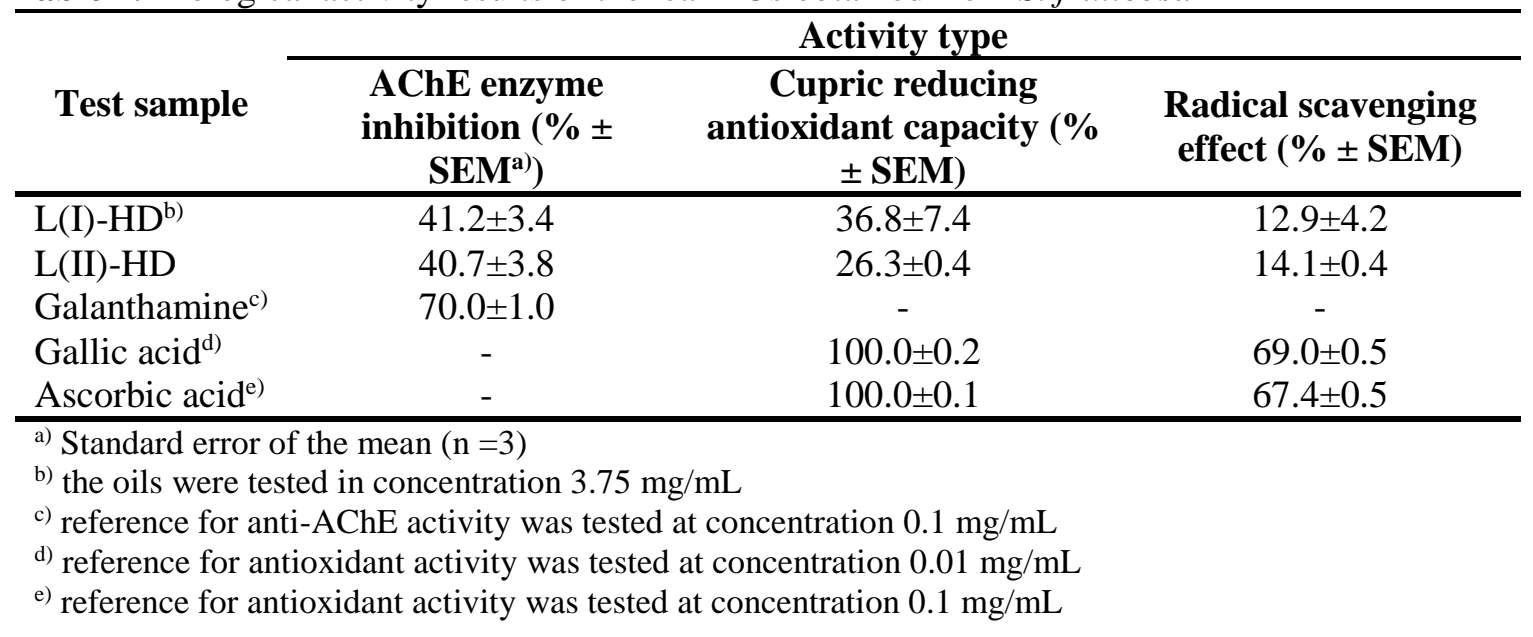




\subsection{Antioxidant Activity of Essential Oil}

It is known that antioxidants may act as free radical scavengers (DPPH ${ }^{\bullet}$ scavenging assay), as reducing agents (cupric ions) or as hydrogen atom donors (inhibition of linoleic acid oxidation) [90]. In scope of the present work, two different tests were applied to assess antioxidant properties of $S$. fruticosa EOs. The CUPRAC assay allowed us to measure the total antioxidant potential of EOs. This method is based on reduction of $\mathrm{Cu}$ (II) to $\mathrm{Cu}$ (I) by antioxidants present in the sample. A chromogenic reagent, neocuproine (2,9-dimethyl-1,10-phenanthroline), forms a complex with $\mathrm{Cu}(\mathrm{I})$, which has a maximum absorbance at $450 \mathrm{~nm}$. Cupric reducing capacity of the tested EOs was found to be moderate (26-37\%) in comparison to ascorbic and gallic acids which were used as reference reducing compounds.

Among the antioxidant activity measuring tests, DPPH free radical scavenging assay is the most extensive applied test. The reaction between antioxidant compounds and DPPH radicals behaves like an electron transfer reaction [91] . As represented in Table 2, the free radical scavenging potential (13-14\%) of the both oils of $S$. fruticosa against DPPH radicals was found to be lower in comparison to ascorbic and gallic acids used as the reference compounds.

\section{Conclusion}

The oxygenated monoterpenes (62.4-69.3\%) were found to be predominating compound group with 1,8-cineole and camphor as the main constituents in all the tested samples with exception of the gall oil in which oxygenated sesquiterpenes $(25.6 \%)$ and diterpenes $(17.3 \%)$ were detected in high percentages. Qualitative differences of the volatiles obtained by HD and MSD-SPME techniques from the leaf and the galls are reported here first. The major compounds were found to be similar in the composition of leaf and gall essential oil of S. fruticosa which were collected from three different regions of Turkey. The amounts of the major compounds in the essential oil differed according to region, essential oil processing methods (HD or MSD-SPME) and parts of the plant.

\section{Acknowledgement}

We are grateful to Professor Ertan Tuzlacı for collected the S. fruticosa from Muğla-Torba. We also thank him sharing the photo of the plant.

\section{Supporting Information}

Supporting information accompanies this paper on http://www.acgpubs.org/journal/records-ofnatural-products

\section{ORCID}

Sevda Süzgeç-Selçuk: 0000-0002-1552-7521

Temel Özek: 0000-0003-4251-8783

Gülmira Özek: 0000-0001-8908-6098

Süleyman Yur: 0000-0001-5980-4992

Fatih Göger : 0000-0002-9665-0256

M. Bahar Gürdal : 0000-0003-4009-100X

Gizem Gülsoy Toplan : 0000-0002-0544-2532

Ali H. Meriçli : 0000-0001-6393-9427

K.Hüsnü Can Başer: 0000-0003-2710-0231

\section{References}

[1] F. Celep and T. Dirmenci (2017). Systematic and biogeographic overview of Lamiaceae in Turkey, Nat. Volat. Essent. Oils, 4, 14-27. 
[2] K.H.C. Baser and N. Kirımer (2018). Essential oils of Anatolian Lamiaceae - An update, Nat. Volat. Essent. Oils, 5, 1-28.

[3] Hedge, I. C. in 'Salvia L.', Ed. P. H. Davis (1982). Flora of Turkey and the East Aegean Islands 7, University of Edinburgh Press, Edinburgh, pp. 400-461.

[4] D. Rivera, C. Obon and F. Cano (1994). The botany, history and traditional uses of three-lobed sage (Salvia fruticosa Miller) (Labiatae), Econ. Bot. 48, 190-195.

[5] S. D. Hatipoglu, N. Zorlu, T. Dirmenci, A. C. Goren, T. Ozturk and G. Topcu (2016). Determination of volatile organic compounds in fourty five Salvia species by thermal desorption-GC-MS technique, Rec. Nat. Prod. 10, 659-700.

[6] K. H. C. Baser (2002). Aromatic biodiversity among the flowering plant taxa of Turkey, Pure Appl. Chem. 74, 527-545.

[7] Baser, K.H.C. (2000). Production of Salvia oil in Mediterranean countries. In: Kintzios, S.E., editor. Sage the Genus Salvia. Harwood Academic Publishers, Amsterdam, The Netherlands, pp. 263-268.

[8] N. A. Jaradat, O. I. Ayesh and C. Anderson (2016). Ethnopharmacological survey about medicinal plants utilized by herbalists and traditional practitioner healers for treatments of diarrhea in the West Bank/Palestine, J. Ethnopharmacol. 182, 57-66.

[9] H. Gali-Muhtasib, C. Hilan and C. Khater (2000). Traditional uses of Salvia libanotica (East Mediterranean sage) and the effects of its essential oils, J. Ethnopharmacol. 71, 513-520.

[10] I. Uysal, S. Gucel, T. Tutenocakli and M. Ozturk (2012). Studies on the medicinal plants of AyvacikÇanakkale in Turkey, Pak. J. Bot. 44, 239-244.

[11] E. Tuzlacı (2005). Bodrum'da Bitkiler ve Yaşam. Ali Rıza Baskan, Güzel Sanatlar Matbaası A.Ş, Istanbul.

[12] R. Boukhary, K. Raafat, A. I. Ghoneim, M. Aboul-Ela and A. El-Lakany (2016). Anti-inflammatory and antioxidant activities of Salvia fruticosa: An HPLC determination of phenolic contents, Evid-Based Compl. Alt. Med. ID 7178105, six pages.

[13] C. Saricoban and M. Ozcan (2004). Antioxidative activity of rosemary (Rosmarinus officinalis L.) and sage (Salvia fruticosa L.), Essent. Oils Chicken Fat. 7, 91-95.

[14] M. Vergine, F. Nicolì, C. Negro, A. Luvisi, E. Nutricati, R. A. Accogli, E. Sabella and A. Miceli (2019). Phytochemical profiles and antioxidant activity of Salvia species from Southern Italy, Rec. Nat. Prod. 13, 205-215.

[15] N. Sarac and A. Ugur (2009). The in vitro antimicrobial activities of the essential oils of some Lamiaceae species from Turkey, J. Med. Food. 12, 902-907.

[16] V. Exarchou, L. Kanetis, Z. Charalambous, S. Apers, L. Pieters, V. Gekas and V. Goulas (2015). HPLCSPE-NMR characterization of major metabolites in Salvia fruticosa Mill. extract with antifungal potential: Relevance of carnosic acid, carnosol, and hispidulin, J. Agr. Food Chem. 63, 457-463.

[17] C. P. R. Xavier, C. F. Lima, M. Fernandes-Ferreira and C. Pereira-Wilson (2009). Salvia fruticosa, Salvia officinalis, and rosmarinic acid induce apoptosis and inhibit proliferation of human colorectal cell lines: The role in MAPK/ERK Pathway, Nutr. Cancer. 61, 564-571.

[18] S. Arabiyat, A. Al-Rabi'ee, H. Zalloum, M. Hudaib, M. Mohammad and Y. Bustanji (2016). Antilipolytic and hypotriglyceridemic effects of dietary Salvia triloba Lf (Lamiaceae) in experimental rats, Trop. J. Pharm. Res. 15, 723-728.

[19] M. Perfumi, N. Arnold and R. Tacconi (1991). Hypoglycemic activity of Salvia fruticosa Mill. from Cyprus, J. Ethnopharmacol. 34, 135-140.

[20] F. S. Senol, I. E. Orhan, S. A. Erdem, M. Kartal, B. Sener, Y. Kan, F. Celep, A. Kahraman and M. Dogan (2011). Evaluation of cholinesterase inhibitory and antioxidant activities of wild and cultivated samples of Sage (Salvia fruticosa) by activity-guided fractionation, J. Med. Food. 14, 1476-1483.

[21] S. U. Savelev, E. J. Okello and E. K. Perry (2004). Butyryl- and acetyl-cholinesterase inhibitory activities in essential oils of Salvia species and their constituents, Phytother. Res. 18, 315-324.

[22] V. Kasabri, F. U. Afifi, R. Abu-Dahab, N. Mhaidat, Y. K. Bustanji, I. M. Abaza and S. Mashallah (2014). In vitro modulation of metabolic syndrome enzymes and proliferation of obesity related-colorectal cancer cell line panel by Salvia species from Jordan, Rev. Roum. Chim. 59, 693-705.

[23] S. S. Erdogan, U. Karik and K. H. C. Baser (2011). The determination of total phenolics and flavonoid contents, and antioxidant activity of some sage populations of Salvia fruticosa Mill., Salvia pomifera Mill. and Salvia tomentosa Mill. in the Marmara region of Turkey, Planta Med. 77, 1319-1319.

[24] N. H. El-Sayed, T. I. Khalifa, M. T. Ibrahim and T. J. Mabry (2001). Constituents from Salvia triloba, Fitoterapia 72, 850-853.

[25] S. Duletić-Laušević, A. Alimpić Aradski, K. Šavikin, A. Knežević, M. Milutinović, T. Stević, J. Vukojević, S. Marković and P.D. Marin (2018). Composition and biological activities of Libyan Salvia fruticosa Mill. and S. lanigera Poir. extracts, S. Afr. J. Bot. 117, 101-109. 
[26] I. Mathe, A. Mathe, J. Hohmann and G. Janicsak (2010). Volatile and some non-volatile chemical constituents of Mediterranean Salvia species beyond their native area, Isr. J. Plant Sci. 58, 273-277.

[27] N. Azcan, A. Ertan, B. Demirci and K. H. C. Baser (2004). Fatty acid composition of seed oils of twelve Salvia species growing in Turkey, Chem. Nat. Compd. 40, 218-221.

[28] M. M. Ozcan, G. Figueredo, J. C. Chalchat, P. Chalard, F. Al Juhaimi, K. Ghafoor and E. F. El Babiker (2015). Chemical constituents in essential oils of Salvia officinalis L. and Salvia fruticosa Mill., Z. ArzneiGewurzpla. 20, 181.

[29] M. S. Ali, A. K. Y. Dardass, S. Ahmad, M. Saleem, S. Firdous and V. U. Ahmad (2000). Two new diterpenoids from Salvia triloba, Fitoterapia 71, 347-352.

[30] G. Topcu, M. Ozturk, T. Kusman, A. A. Barla Demirkoz, U. Kolak and A. Ulubelen (2013). Terpenoids, essential oil composition and fatty acids profile, and biological activities of Anatolian Salvia fruticosa Mill., Turk. J. Chem. 37, 619-632.

[31] U. Karik, A. C. Saglam, M. Kurkcuoglu and K. H. C. Baser (2011). Compositions of the essential oils of Salvia fruticosa Mill. Populations in the Flora of Marmara Region, Planta Med. 77, 1302-1302.

[32] J. C. Chalchat, M. M. Ozcan, G. Figueredo (2011). The composition of essential oils of different parts of laurel, mountain tea, aage and ajowan, J. Food Biochem. 35, 484-499.

[33] I. Kocabas, M. Kaplan, M. Kurkcuoglu and K. H. C. Baser (2010). Effects of different organic manure applications on the essential oil components of Turkish sage (Salvia fruticosa Mill.), Asian J. Chem. 22, $1599-1605$.

[34] I. E. Orhan, F. S. Senol, M. Z. Haznedaroglu, H. Koyu, S. A. Erdem, G. Y1lmaz, M. Cicek, A. E. Yaprak, E. Ari and N. Kucukboyaci (2016). Neurobiological evaluation of thirty-one medicinal plant extracts using microtiter enzyme assays, Clin. Phytosci. 2, 1-12.

[35] R. Briggs, S. P. Kennelly and D. O'Neill (2016). Drug treatments in Alzheimer's disease, Clin. Med. 16, 247-253.

[36] H. Mitsumoto (1997). Diagnosis and progression of ALS. Neurology 48(4 Suppl 4), 2S-8S.

[37] M.M. Mehndiratta, S. Pandey and T. Kuntzer (2014). Acetylcholinesterase inhibitor treatment for myasthenia gravis, Cochrane Datab.Syst. Rev.10, CD006986.

[38] J. Sirviö, J.O. Rinne, A. Valjakka, U.K. Rinne, P.J. Riekkinen, and L. Paljärvi (1989). Different forms of brain acetylcholinesterase and muscarinic binding in Parkinson's disease, J. Neurol. Sci. 90, 23-32.

[39] I. Erdogan Orhan (2012). Current concepts on selected plant secondary metabolites with promising inhibitory effects against enzymes linked to alzheimer's disease, Curr. Med. Chem. 19, 2252-2261.

[40] T. Thomsen and H. Kewitz (1990). Selective inhibition of human acetylcholinesterase by galanthamine in vitro and in vivo, Life Sci. 46, 1553-1558.

[41] B. Zhao, S. M. Moochhala and S.Y. Tham (2004). Biologically active components of Physostigma venenosum, J. Chromatogr.B 812, 183-192.

[42] X. Ma and D. R. Gang (2004). The Lycopodium alkaloids, Nat. Prod. Rep. 21, 752-772.

[43] A. Saklani and S. K. Kutty (2008). Plant-derived compounds in clinical trials, Drug Discov. Today, 13, 161171.

[44] G. Topcu and T. Kusman (2014). Lamiaceae family plants as a potential anticholinesterase source in the treatment of Alzheimer's disease, Bezmialem Science 1, 1-25.

[45] R. Tundis, M. R. Loizzo, M. Bonesi, F. Menichini, V. Mastellone, C. Colica and F. Menichini (2012). Comparative study on the antioxidant capacity and cholinesterase inhibitory activity of Citrus aurantifolia Swingle, C. aurantium L., and C. bergamia Risso and Poit. peel essential oil. J. Food Sci. 77, H40-H46.

[46] M. R. Loizzo, F. Menichini, F. Conforti, R. Tundis, M. Bonesi, A. M. Saab, G. A. Statti, B. d. Cindio, P. J. Houghton, F. Menichini and N. G. Frega (2009). Chemical analysis, antioxidant, antiinflammatory and anticholinesterase activities of Origanum ehrenbergii Boiss and Origanum syriacum L. essential oils, Food Chem. 117, 174-180.

[47] P. K. Mukherjee, V. Kumar, M. Mal and P. J. Houghton (2007). In vitro acetylcholinesterase inhibitory activity of the essential oil from Acorus calamus and its main constituents, Planta Med. 73, 283-285.

[48] N. S. Perry, P. J. Houghton, P. Jenner, A. Keith and E. K. Perry (2002). Salvia lavandulaefolia essential oil inhibits cholinesterase in vivo, Phytomedicine 9, 48-51.

[49] F. S. Senol, I. Orhan, F. Celep, A. Kahraman, M. Dogan, G. Yilmaz and B. Sener (2010). Survey of 55 Turkish Salvia taxa for their acetylcholinesterase inhibitory and antioxidant activities, Food Chem. 120, 3443.

[50] M. E. Duru, G. Tel, M. Öztürk and M. Harmandar (2012). Chemical composition, antioxidant and anticholinesterase activities of the essential oil of Salvia chrysophylla Staph., Rec. Nat. Prod. 6, 175-179.

[51] European Pharmacopoeia, Council of Europe, Strasbourg, France, 2005. 
[52] G. Özek, F. Demirci, T. Özek, N. Tabanca, D. E. Wedge, S. I. Khan, K. H. C. Baser, A. Duran and E. Hamzaoglu (2010). Gas chromatographic-mass spectrometric analysis of volatiles obtained by four different techniques from Salvia rosifolia Sm., and evaluation for biological activity, J. Chromatogr. A 1217,741-748.

[53] D. Joulain, W. König and D. Hochmuth (2001). Library of MassFinder. Terpenoids and related constituents of essential oils, 2, 90.

[54] R. P. Adams (1997). Identification of essential oil components by Gas Chromatography/Mass Spectroscopy. J. Am. Soc. Mass Spectrom. 6, 671-672.

[55] NIST Chemistry WebBook, https://webbook.nist.gov/chemistry/, Last update to data:2018

[56] Wiley Registry, Mass Spectral Library, 11th Edition / NIST 2017, https://www.wiley.com

[57] K. H. C. Baser and F. Demirci (2007). in 'Chemistry of Essential Oils', Ed. R. F. Berger, Springer-Verlag, Berlin, Heidelberg.

[58] A. Adsersen, B. Gauguin, L. Gudiksen and A. K. Jäger (2006). Screening of plants used in Danish folk medicine to treat memory dysfunction for acetylcholinesterase inhibitory activity, J. Ethnopharmacol. 104, 418-422.

[59] R. Apak, K. Güçlü, M. Özyürek, B. Bektasoğlu and M. Bener (2008). Cupric ion reducing antioxidant capacity assay for food antioxidants: vitamins, polyphenolics, and flavonoids in food extracts, Advan. Protocol. Oxidat. Stress I, 163-193.

[60] W. Brand-Williams, M.-E. Cuvelier and C. Berset (1995). Use of a free radical method to evaluate antioxidant activity, LWT-Food Sci Technol. 28, 25-30.

[61] R. Zgheib, C. Yassine, S. Samar Azzi-Achkhouty and M. El Beyrouthy (2019). Investigation of essential oil chemical polymorphism of Salvia fruticosa naturally growing in Lebanon, J. Essent. Oil. Bearing Plants 22, 408-430.

[62] V. I. Babushok, P. J. Linstrom and I. G. Zenkevich (2011). Retention indices for frequently reported compounds of plant essential oils, J. Phys. Chem. Ref. Data 40(4), 043101. 61.

[63] D. E. Wedge, J. A. Klun, N. Tabanca, B. Demirci, T. Ozek, K. H. C. Baser, Z. Liu, S. Zhang, C. L. Cantrell and J. Zhang (2009). Bioactivity-guided fractionation and GC/MS fingerprinting of Angelica sinensis and Angelica archangelica root components for antifungal and mosquito deterrent activity, J. Agr. Food Chem. 57, 464-470.

[64] A. Gauvin, H. Ravaomanarivo and J. Smadja (2004). Comparative analysis by gas chromatography mass spectrometry of the essential oils from bark and leaves of Cedrelopsis grevei Baill, an aromatic and medicinal plant from Madagascar, J. Chromatogr. A, 1029, 279-282.

[65] A. Raal, H. Kaur, A. Orav, E. Arak, T. Kailas and M. Mueuerisepp (2011). Content and composition of essential oils in some Asteraceae species, P. Est. Acad. Sci. 60, 55.

[66] S. F. Hachicha, T. Skanji, S. Barrek, Z.G. Ghrabi and H. Zarrouk (2007). Composition of the essential oil of Teucrium ramosissimum Desf. (Lamiaceae) from Tunisia, Flavour Fragr. J. 22, 101-104.

[67] T. Kundakovic, N. Fokialakis, N. Kovacevic and I. Chinou (2007)._Essential oil composition of Achillea lingulata and A. umbellata, Flavour Fragr. J. 22, 184-187.

[68] A. Gil, C. M. Van Baren, P.M.D.L. Lira and A.L. Bandoni (2007). Identification of the genotype from the content and composition of the essential oil of lemon verbena (Aloysia citriodora Palau), J. Agric. Food Chem. 55, 8664-8669.

[69] A. Bendiabdellah, M. El Amine Dib, N. Djabou, H. Allali, B. Tabti, A. Muselli and J. Costa (2012). Biological activities and volatile cinstituents of Daucus muricatus L. from Algeria, Chem. Centr. J. 6, 48, 110 .

[70] E.M. Suleimenov,_G.A. Atazharova, B. Demirci, K.H.C. Baser and S.M. Adekenov (2003). Essential oil composition of Artemisia lercheana and A. sieversiana of Kazakhstan flora in recent problems of development of new medicines of natural origin, Proceedings of Symposium, St.Petersburg - Pushkin, 2003, 382-385.

[71] I.M. Hulley, G. Özek, N.J. Sadgrove, P. M. Tilney, T. Özek, K.H.C. Başer, and B. E. Van Wyk (2019). Essential oil composition of a medicinally important Cape species: Pentzia punctata (Asteraceae). S. Afr. J. Bot. 127, 208-212.

[72] K.C. Wong and F.Y. Lai (1996). Volatile constituents from the fruits of four Syzygium species grown in Malaysia, Flavour Fragr. J. 11, 61-66.

[73] K. Polatoğlu, F. Demirci, B. Demirci, N. Gören and K. H. C. Başer (2012). Essential oil composition and antimicrobial activities of Tanacetum chiliophyllum (Fisch. \& Mey.) Schultz Bip. var. monocephalum Grierson from Turkey, Nat. Prod. Res. 6(2), 184-188.

[74] C. D. Frizzo, L. A. Serafini, E. Dellacassa, D. Lorenzo and P. Moyna (2001) Essential oil of Baccharis uncinella DC. from Southern Brazil, Flavour Fragr. J. 16, 286-288. 
[75] M. Miyazawa and N. Tamura (2007). Components of the essential oil from sprouts of Polygonum hydropiper L. ('Benitade'), Flavour Fragr. J. 22, 188-190.

[76] H. Noorizadeh and A. Farmany (2010). Exploration of linear and nonlinear modeling techniques to predict of retention index of essential oils, J. Chin. Chem. Soc. 57,1268-1277.

[77] H. F. Sakhanokho, B. J. Sampson, N. Tabanca, D. E. Wedge, B. Demirci, K. H. C. Baser, U. R. Bernier, M. Tsikolia, N. M. Agramonte, J. J. Becnel, J. Chen, K. Rajasekaran and J.M. Spiers (2013). Chemical composition, antifungal and insecticidal activities of Hedychium essential oils, Molecules, 18(4), 4308-4327.

[78] L. V. Kosyukova and T. V. Khorguani (1989). Retention indices of diterpenes isolated from resins of coniferous trees, Zh. Anal. Khim. 44, 1309-1313.

[79] M. Sylvestre, A. Pichette, A. Longtin, F. Nagau and J. Legault (2006). Essential oil analysis and anticancer activity of leaf essential oil of Croton flavens L. from Guadeloupe, J. Ethnopharmacol. 103, 99-102.

[80] A. C. U. Lourens, D. Reddy, K. H. C. Baser, A. M. Viljoen and S. F. Van Vuuren (2004). In vitro biological activity and essential oil composition of four indigenous South African Helichrysum species, J. Ethnopharmacol. 95, 253-258.

[81] K. H. C. Baser, G. Özek, T. Özek, A. Duran and H. Duman (2006). Composition of the essential oils of Rhabdosciadium oligocarpum (Post ex Boiss.) Hedge et Lamond and Rhabdosciadium microcalycinum Hand.-Mazz., Flavour Fragr. J. 21, 650-655.

[82] H. Van Den Dool and P. D. Kratz (1963). A generalization of the retention index system including linear temperature programmed gas-liquid partition chromatography, J. Chromatogr. 11, 463-471.

[83] K. Polatoglu, F. Demirci, B. Demirci, N. Goren and K. H. C. Baser (2010). Antimicrobial activity and essential oil composition of a new T. argyrophyllum (C. Koch) Tvzel var. argyrophyllium chemotype, J. Oleo Sci. 59, 307-313.

[84] B. Sen Utsukarci, B. Gurdal, M. Bilgin, D. Satana, B. Demirci, N. Tan and A. Mat (2019). Biological activities of various extracts from Salvia cassia Sam. ex Rech. f. and chemical composition of its most active extract, Rec. Nat. Prod. 13, 24-36.

[85] F.Abak, G.Yildiz, A.Atamov and M. Kürkçüoğlu (2018). Composition of the essential oil of Salvia montbretii Benth. from Turkey, Rec. Nat. Prod. 12, 426-431.

[86] M.R. Tellez, I. A. Khan, B. T. Schaneberg, S. L. Crockett, A. M. Rimando and M.Kobaisy (2004). Steam distillation-solid-phase microextraction for the detection of Ephedra sinica in herbal preparations, J. Chromatogr. A 1025, 51-56.

[87] G. Özek, T. Özek, K.H.C. Baser, A. Duran, M. Sagiroglu and H. Duman (2006). Comparison of the essential oils of Prangos turcica A. Duran, M. Sagiroglu et H. Duman fruits obtained by different isolation techniques, J. Essent. Oil Res. 18, 511-514.

[88] T. Özek, G. Özek, K. Baser and A. Duran (2005). Comparison of the essential oils of three endemic Turkish Heracleum species obtained by different isolation techniques, J. Essent. Oil Res. 17, 605-610.

[89] M. Pohanka, M. Hrabinova, K. Kuca and J.-P. Simonato (2011). Assessment of acetylcholinesterase activity using indoxylacetate and comparison with the standard Ellman's Method, Int. J. Mol. Sci. 12, 2631-2640.

90] K. Mishra, H. Ojha and N. K. Chaudhury (2012). Estimation of antiradical properties of antioxidants using DPPH assay: A critical review and results, Food Chem. 130, 1036-1043.

[91] M. C. Foti, C. Daquino and C. Geraci (2004). Electron-transfer reaction of cinnamic acids and their methyl esters with the DPPH' radical in alcoholic solutions, J. Org. Chem. 69, 2309-2314.

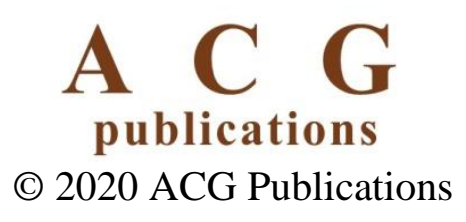

